\title{
Global crisis and credit risk management by banks: A comparative study of banks in Pakistan
}

\author{
Azam Ali ${ }^{1}$, Saghir Pervaiz Ghauri ${ }^{2}$ \\ ${ }^{1}$ Statistics \& DWH Department, State bank of Pakistan, Karachi, Pakistan \\ ${ }^{2}$ Research Department, State bank of Pakistan, Karachi, Pakistan \\ Email address: \\ azam.ali@sbp.org.pk (A. Ali), Saghir.pervaiz@sbp.org.pk (S. P. Ghauri)
}

To cite this article:

Azam Ali, Saghir Pervaiz Ghauri. Global Crisis and Credit Risk Management by Banks: A Comparative Study of Banks in Pakistan. International Journal of Business and Economics Research. Vol. 2, No. 6, 2013, pp. 158-168. doi: 10.11648/j.ijber.20130206.15

\begin{abstract}
The world trade environment has worsened significantly after August 2007. The rapid and dynamic changes in the global financial landscape pose various risks to banking institutions. Operating side by side with conventional banks, Islamic banks are equally vulnerable to risks. This paper examines the impact of global financial crisis on the credit risk management of banks operating in Pakistan during the period, 2007-2009. A comparison of the factors, affecting credit risk faced by these banks, is highlighted. Study finds that, whilst the Islamic banking industry has not been left unaffected by the global crisis, Islamic banks in Pakistan are in a relatively strong position. This is because of the industry's high levels of transparency and adherence to a strict code of business conduct and Management efficiency, which means that Islamic banks have the potential to emerge from the crisis in a stronger position than their conventional counterparts.
\end{abstract}

Keywords: Global Financial Crisis, Credit Risk, Pakistan, Islamic Banks, Conventional Banks

\section{Introduction}

The Global Financial Crisis (GFC) began in August 2007, implemented a series of changes directed at ensuring that liquidity would be distributed to those institutions that need it most (Stephen G. Cecchetti, June-2008). During 2008 the GFC and economic downturn increased the uncertainty and negatively affected the world economy. The greatest risks posed to banks take the form of credit risk. The crisis has clearly demonstrated the importance of risk management. The crisis was the product of a 'perfect storm' beginning together a number of microeconomic and macroeconomic pathologies (William H. Buiter, Dec-2007). The credit crisis of 2007 began with the deterioration in the United States. Given that the financial system is at the epicenter of the global crisis, it is unsurprising that the US and UK are among the countries that suffer the most significant deterioration in their business environments. The US's global ranking declines from $7^{\text {th }}$ to $12^{\text {th }}$ and UK's to $25^{\text {th }}$ in the forecast period 2009-13 (Special Report May 2009, the economist Intelligence Unit Limited).

The world trade environment has worsened significantly over the recent past. According to World Bank, since the G20 leaders signed a pledge in November 2008 to avoid protectionist measures, several countries, including 17 of the G20, have implemented a total of 47 measures that restrict trade. Another 78 protectionist measures have been proposed, but WTO has noted a 'significant slippage' globally towards trade protectionism. Recent examples of protectionism include Russia raising tariffs on used car imports and Ecuador raising on more than 600 items.

The causes behind the recent global financial crisis are complex, and are linked to the financial market decline. In US economy, banking industry has been badly hit due to mortgages backed by subprime mortgages fallen in value. Due to bad debts financial institutions were reluctant to lend money and thus firm especially construction industry's output faced contractions in credit lines which contributes $15 \%$ of US output (Mvula, 2008).

Credit risk in banking is commonly defined as the probability of a borrower default to his loan commitments. Credit risk in an Islamic bank is in the form of settlement/payment risk arising when one party to a business transaction pays money (for example Salam or Istisna contract) or deliver assets (Murabahah contract) before receiving its own assets or cash, thereby exposing it to potential loss (Khan and Ahmed, 2001).

Despite that numerous methodologies are adopted by the researchers to measure credit risks and to predict bankruptcy, everyone agrees that credit risk management 
has been very important issue. The majority of financial analysts used the subjective analysis for assessment of credit risk. Credit risk assessment models comprise Qualitative and Quantitative methods, Logistic Regression Models and causal \& hybrid Models. The credit institutions face a variety of risks, but credit risk is probably the most popular one (Lampros and Loannis, 2006).

Though banks in Islamic system face fewer solvency and liquidity risks than their conventional counterparts, efficacy of their credit operations is extremely important that provides basis for ensuring the solvency of debtors. Credit risk comprises default risk, down grade risk, counter party risk and settlement risk. It covers $80 \%$ in an average bank's banking book asset portfolio. It is the cause of $80 \%$ bank failures (Tariqullah, 2002). It is the main risk that Islamic banks face in operations that mainly becomes the cause of market risks and liquidity risks.

As the slump in the global economy prevailed, the Pakistan's economy witnessed a period of significant instability and a deterioration of most macroeconomic indicators. The timing of the crisis, and Pakistan's response to domestic developments might seem contradictory to a layman. As governments around the world lowered interest rates and implemented expansionary fiscal measures to revitalize their economies, Pakistan underwent a phase of fiscal tightening, and a stringent monetary stance with discount rates remaining relatively high for most of the period (discount rates remained at 15 percent till April 2009).

Pakistan's economy has been under strain due to excess demand pressures that have been building since 2004. The combined effects of global food, fuel and financial crisis took quite a toll on the economy as the current account balance and fiscal deficits increased, inflation surged the South Asia Region. Fortunately, strong corrective actions have been taken over the past period, including an IMF program in November that is helping stabilize the Pakistani economy.

The effects of the global slowdown in Pakistan have been transmitted through the trade balance; with a slowdown in global demand and fall in commodity prices having varying effects, the capital account; with a significant reduction in private inflows to Pakistan.

Though overall Pakistan banking sector is less affected by global financial crisis, Islamic banks succeeded in managing their credit risk due to their business nature, prohibition on the concept of banking on 'money on money' rather prefer to do business for social welfare through financing on asset backed banking. Islamic banks do not allow 'Financial derivatives' despite the fact that, they are frequently used by their conventional counterparts.

The next section comprises the brief discussion about banking industry in Pakistan In section 3 we reviewed relevant literature. Section 4 constitutes methodology, data specification and model description. An empirical analysis is done in section 5. Contribution to literature of present study is presented in section 6 . Section 7 concludes the paper with recommendations in section 8 .

\section{Pakistan Banking Industry}

The financial system in Pakistan has evolved over the years in response to growth of the economy and government plans for the development of the country. The system comprised the Central bank (State bank of Pakistan (SBP)), Commercial banks, Microfinance banks, Specialized banks, and a mix of Non-Bank Financial Institutions (NBFIs) including Development Financial Institutions (DFIs), Investment banks, housing finance companies, leasing companies, modarabas and mutual funds, brokerage houses and insurance companies. Three Stock Exchanges at Karachi, Lahore and Islamabad are also a part of Financial System in Pakistan. In addition to managing the monetary policy, SBP also regulates banks and DFIs. Securities and Exchange Commission of Pakistan (SECP) supervises few of from a mix of Non-bank Financial Institutions (NBFIs) which includes: investment banks, leasing companies, insurance companies, modarbas and mutual funds.

Pakistan's banking sector is made up of 53 banks of which 36 are commercial banks (includes six full fledge Islamic banks), four specialized banks, seven development financial institutions and six micro-finance banks.

\subsection{Islamic Banking}

Islamic banking today is an industry that is still evolving. The growth of Islamic banking is a result of economic growth in the Islamic world. Islamic banks around the world have devised many financial products based on the risk-sharing and profit-sharing principles of Islamic banking. For day to day banking activities, a number of financial instruments have been developed that satisfy the Islamic doctrine and provide acceptable financial returns for investors. Broadly speaking, the areas in which Islamic banks are most active are in trade and commodity finance and leasing.

Some countries endorse special laws for Islamic banking to organize the operations of Islamic banks and their relations with the central bank. Islamic banks are also exposed to credit risk. It is a counter-party risk inherent in some modes of Islamic finance. Exposure to such risk is increased by the absence of well developed credit risk assessment systems and associated expertise for Islamic banks. The central bank develops and implements rules that ensure the healthiness of the financial conditions of the Islamic banks. It enforces a number of mandatory financial ratios and rules.

The total assets of the Islamic banking industry in Pakistan are over Rs. 313 billion as of 30 th June, 2009 which accounts for a market share of 5.2\% of total banking industry assets. Based on the factors like unmet demand, geographical coverage, product development, new segments and data collected by different Islamic banks, it is estimated that total assets of Islamic banking industry will reach over one trillion rupees up to year 2012 (SBP Review, 2009). 
The increasing global interest in Islamic banking is due to a phenomenal and rapid growth of Islamic finance in the Islamic countries as well as other parts of the world during the past two decades. Major international Islamic banks, Conventional banks through their Islamic branches/special windows and specialized financial institutions offer Islamic products catering to growing Muslim presence in these markets.

\section{Literature Review}

In this section, we provide a brief review of the literature to place our paper in context. Our research is related to two strands of literature: the measurement of banks' Credit risk Management and the effect of Global Financial Crisis. We discuss these literatures in turn.

\subsection{Global Financial Crisis}

The amplification of the global financial crisis, following the bankruptcy of Lehman Brothers in September 2008, has made the economic and financial environment a very difficult time for the world economy, the global financial system and for central banks (Dr Rakesh Mohan). The GFC has shown that markets can fail with huge costs. The financial system is prone to excesses, given the high leverage of banks. banks effectively act as trustee of public funds through their deposit taking activities and payment systems. A failure of one bank can have a strong a strong contagion on the rest of the banks, even if they are healthy. In this age of globalisation, as the GFC has revealed, the lack of confidence in banks in one country can also have a contagion on the rest of the world. Financial institutions in developing countries haven't been effected by financial crisis in developing countries due to of usage of traditional financial system where unlike US, individuals and groups need to have good track record in order to gain credit or loans and therefore risk is minimal. As according to Fitch Ratings, the international credit rating agency with head offices in New York and London, 'the Pakistani banking system has, over the last decade, gradually evolved from a weak state-owned system to a slightly healthier and active private sector driven system', Pakistan's banking sector has not been as prone to external shocks as have been banks in Europe. However, banks in developing economies have to suffer contractions in credit lines and reduced financial flows.

The global financial crisis hit South Asia at a time when it had just recovered from severe terms of trade shock resulting from the global food and fuel price crisis. The food and fuel price shocks had badly affected South Asia, with cumulative income loss ranging from 34 percent of 2002 GDP for Maldives to 8 percent for Bangladesh. Pakistan, Sri Lanka, and Maldives were particularly vulnerable because difficult political and social environments prevented adequate policy measures to adjust to the terms of trade shock. Additionally, their reliance on foreign funding has been relatively large. The global financial crisis worsened their macroeconomic difficulties as sources of funding contracted. (The Daily DAWN, Pakistan, February 04, 2008)

The causes behind the recent global crisis are complex, and are linked to the financial market decline. In US economy, banking industry has been badly hit due to mortgages backed by subprime mortgages fallen in value. Further, as the bad debts financial institutions were reluctant to lend money, firms especially construction industry's output, faced contractions in credit lines which contributes $15 \%$ of US output (Mvula, 2008).

Pakistan's economy has been under strain due to excess demand pressures that have been building since 2004. The combined effects of global food, fuel and financial crisis took quite a toll on the economy as the current account balance and fiscal deficits increased, inflation surged South Asia Region. Fortunately, strong corrective actions have been taken under the IMF program that is helping stabilize the Pakistani economy. The story in Sri Lanka and Maldives is worrisome. Like Pakistan, these countries have been struggling with excess demand pressures, which have been further aggravated by the global food, fuel and financial crises (South Asia Region, The World bank group, February 17, 2009).

The current financial crisis in the West has critically exposed the vulnerabilities of a liberalized financial system. It has also highlighted the challenges that the policymakers and regulators are faced with in an increasingly globalised, ever-changing world. The domino effect of a trouble sparked by US sub-prime debt defaults underscores apparent and hidden linkages of the complex market capitalism that never ceases to spring surprises.

The banking, other financial institutions, fund and asset management giant firms in the West, meanwhile, came under pressure from depositors and shareholders on how prudent have been their investment and lending policies. Far away from the US and Europe, Pakistan watched at the tumbling of capital markets, keeping its fingers crossed. The local banking hierarchy and fund managers were concerned. But the primary reason for their anxiety was different. They found concerned about the infrastructure deficit particularly energy shortages.

The Global Financial Crisis 2008-09 actually rooted from the closing years of the 20th century when U.S. housing prices, after an uninterrupted, multi-year escalation, began declining. By mid-2008, there was an almost striking increase in mortgage delinquencies. This increase in delinquencies was followed by an alarming loss in value of securities backed with housing mortgages. And, this alarming loss in value meant an equally alarming decline in the capital of America's largest banks and trillion-dollar government-backed mortgage lenders (like Freddie Mac and Fannie Mae; the government-backed mortgage lenders hold some $\$ 5$ trillion in mortgage-backed securities).

According to IMF's World Economic Outlook update (January 28, 2009), the current financial crisis is more global than other period of financial turmoil in the past 60 
years. The extent and severity of the crisis that began with the bursting of the housing bubble in the United States in August 2007 reflects the confluence of several factors: some are familiar from previous, others are new.

$>$ As in previous times of financial turmoil, the pre-crisis period was characterized by (i) surging asset prices that proved unsustainable; (ii) a prolonged credit expansion leading to accumulation of debt; (iii) the emergence of new types of financial instruments; and (iv) the inability of regulators to keep up.

$>$ New this time is the rapid expansion of securitization, which changed incentives for lenders and lowered credit standards. System became fragile because balance sheets became increasingly complex; financial market players were highly leveraged; and they tried on wholesale funding and external risk assessment. Cross-border spillovers intensified after the crisis broke because financial institutions and markets across borders closely linked and risks highly correlated.

\subsection{Credit Risk of Banks}

Credit risk is one of the main risks that seriously affect banks' viability as evident from the 1997 financial crisis. There was a lack of understanding of risks involved in Islamic banking. This gap justifies new efforts to examine as to why Islamic banking experiences increasing bad loans and high credit risk. This entails an investigation on the factors influencing Islamic banking credit risk. To ensure that the viability and sustainable growth of Islamic banking is maintained, it is important that these factors be identified early to ensure necessary precautions and preventions are taken. It is a modest attempt in this paper to investigate: how global financial crises influenced credit risk of banking industry by focusing on two Islamic banks and two conventional banks in Pakistan?

Sufian et al (2008) investigated the performance of Malaysian Islamic banking sector during the period of 2001-2005. Several efficiency estimates of individual banks were evaluated using non-parametric Data Envelopment Analysis (DEA). They found that during the period of study, scale inefficiency dominated pure technical inefficiency in the Malaysian Islamic banking sector and found that foreign banks exhibited higher technical efficiency compared to its domestic peers.

John B. Caoutte et al (2008) explained different credit risk models and gave reasons to explain 'who needs these models for the analyses'. The authors also discussed the relevance of credit models to the decision makers. The book has a full length chapter on credit risks models based on accounting data and market values, where they elaborated the portfolio models and varieties of Altman Zscore model.

Hamid and Naseer (2007), in their book entitled 'Islamic banking and Finance', explained in details the process and uses of Islamic Financial Instruments, Islamic banking \& finance principles and concepts with specific focus on the financial requirements, duties, ownership, control and risk management of Islamic banks.

Credit derivatives can also be used to express credit risks (Michal et al 2006). The authors identified the problem of credit risk in relation to retail banking and explained why retail credit risk has a dark side. The authors also highlighted the ways of securitization and transfer of consumer risks, commercial risks.

To see the linear dependence or correlation between returns on different assets for very simple portfolios, various GARCH models and Value at Risk model are feasible for forecasting purpose. That is why; firms should be occupied with the risk management tools of volatility and correlation modeling. These models allow the analysts for a quick recalculation of risk measures when the portfolio weights change (Peter F. Kristofferson, 2003).

Sundararajan and Errico (2002) speak out that while PLS modes may shift the direct credit risk of Islamic banks to their investment depositors, they may also increase the overall degree of risk of the asset side of banks' balance sheet since the assets under this mode are un-collaterized. They conclude that the ratio of riskier assets to total assets should typically be higher in an Islamic bank than in conventional bank.

M. Y. Khan (2001) examined banking regulations in India briefly and then analyzed the case of Islamic banks (non-banking financial companies) working in India. He undertook a comparative analysis of Islamic banking and interest-based banking, discussed issues and constraints of Islamic banks, specifically in the Indian context.

A research to Islamic financial institutions in 28 countries by Khan and Ahmed (2001) finds that credit risk is found highest in Musharakah (3.69 from a score of 5) followed by Mudarabah (3.25). Their findings highlight that the bankers perceive profit \& loss sharing (PLS) modes to have higher credit risk. Mark-up risk is found highest in product- deferred contracts of Istisna (3.57).

Analysis of the primary data identified reasons why the supply of loans under profit sharing and joint venture profit sharing is not popular in Malaysia. $40 \%$ to $70 \%$ bankers' surveys indicated that lack of knowledgeable of bankers in selecting, evaluating and managing profitable project is a significant cause (Abdus Samad \& M. Kabir Hassan, 1999) The study evaluates inter-temporal and inter-bank performance of Islamic bank (bank Islam Malaysia Berhad (BIMB) in profitability, liquidity, risk and solvency; and community involvement for the period 1984-1997. The study found that BIMB is relatively more liquid and less risky compared to a group of 8 conventional banks.

Berger and DeYoung (1997) find lagged risk-weighted asset (RWA) is significantly and positively related to credit risk measured by NPLs to total loans. They rationalized that a relatively risky loan portfolio will result in higher NPLs. Lagged Capital measured by equity capital to total assets shows mixed results. For thinly capitalized banks, lagged capital coefficient estimate is significantly but negatively related to risk. This finding supports the moral hazard hypothesis, and suggests that, on an average, thinly 
capitalized banks take more risky loans, which potentially could lead to higher NPLs.

Numerous studies have been conducted to analyze the credit risk analysis of banks. Many researchers have remarkably contributed articles and books in this area. There are number of studies on the analysis of credit risk of conventional banks and Islamic banks in various countries. However, there is hardly one on the analysis of impact of GFC on the credit risk of banks in Pakistan. The uniqueness of our study is that it analyzes the impact of GFC on the credit risk of banks operating in Pakistan by running regression model for the period 2007- 2009.

\section{Methodology \& Data}

By examining closely the relationship between Global financial crisis \& credit risk of Islamic banks and conventional banks, this paper aims to contribute to the existing literature in several ways. First, the paper provides descriptive statistics about Islamic banks and conventional banks credit risk characteristics. Second, it uses regression analysis to determine the underlying factors of global liquidity influencing credit risk of the selected four banks operating in Pakistan during 2007-09.

\subsection{Data}

Data, on the four selected banks operating in Pakistan, extracted from the audited Annual Reports of Individual banks on monthly basis from 2007 to 2009. The study is qualitative as well as quantitative in nature. Descriptive statistics collected from Monthly Statistical Bulletin and Half Yearly Book of Statistics on Scheduled banks utilized for the analysis purpose. Data also supplemented from Islamic banking review (IBR) and banking sector review (BSR) of State bank of Pakistan.

\subsection{Selection Criteria}

We selected two Islamic banks; Meezan bank limited \& Al Baraka Islamic bank B.S.C. (E.C) and two conventional banks; Habib bank limited \& National bank of Pakistan. Among six full fledge Islamic banks operating in Pakistan, Meezan bank is a pioneer Islamic bank in Pakistan and is a pure local Islamic bank with 131 branch network in almost all major cities of country. Al Baraka Islamic bank is the only foreign Islamic bank operating in Pakistan with 29 branch network. The remaining four Islamic banks are small and new as compared to selected ones and found unsuitable to our study of comparison of such specific criteria.

The selection of two conventional banks; Habib bank limited \& National bank of Pakistan was mainly because of the category, branch network and history of these banks. Habib bank is the largest private bank in Pakistan with 1,468 branches all over the country and 47 overseas branches spread in 18 countries including USA, UAE,
France, Turkey, Bahrain and Singapore etc. Similarly, National bank of Pakistan is the only public sector bank with largest branch network in country having 1,261 branches all over the country and 17 overseas branches in 13 countries including USA, Germany, France, Japan, Bahrain and Hong Kong etc. These two banks also maintain foreign exchange portion of foreign exchange reserves of Pakistan (Banking Statistics, State bank of Pakistan, 30.06.2009). The period of study is from 2007 to 2009 because of the nature of the analysis comprises investigation of impact of GFC, which come out from August 2007, on credit risk management of banks in Pakistan.

\subsection{Model Description}

Based on a survey of related literature on risk determinants (Ahmad, 2003; Hassan, 1992, 1993; Hassan et al., 1994; Shrives and Dahl, 1997; Angbazo et al, 1998), several variables have been identified to form the regression model. NPL to total loans is taken as a proxy for credit risk (Rose, 1996; Berger and DeYoung, 1997; Corsetti, Persenti and Roubini, 1998). The estimated predictors consist of nine variables: management efficiency, leverage, "risky sector loan exposure", regulatory capital, loan loss provision, funding cost, Risk-weighted assets, and natural $\log$ of total assets and proportion of loan to deposit (Cafer \& Ferhan, 2005). Risky sector loan, is a very significant factor influencing credit risk of conventional banks but not for Islamic banking. This may to a large extent due to a larger exposure of conventional banks to property- related sectors, construction, share financing and credit consumptions compared to Islamic banking. Taking into consideration this fact and the unavailability of components of risky sector loans (described in the survey) in Pakistani Islamic banks' annual Reports, we decided to modify the model with the exclusion of "risky sector loans" from the original model, consequently decreasing the number of variables from nine to eight.

It is expected that credit risk $(\mathrm{Cr})$ have a negative relationship with Me, LnTA and Rcap. Lower efficiency in managing earning assets would probably lead to higher credit risk; size and capital are risk- related as smaller capitalized bank tend to have lower capacity to absorb losses.

On the other hand, Llp, Fcost, Lev, Rwa and Ld are expected to have positive relationship with credit risk $(\mathrm{Cr})$. A bigger loan loss provision is required if a bank anticipated its credit risk to be higher. Costs related to funding the operations such as loan monitoring, rescheduling and recovery efforts in the event of high problem loans are expected to increase. Similarly, a larger proportion of risk- weighted assets tend to have higher probability of credit risk. 
Islamic Banks Comparison

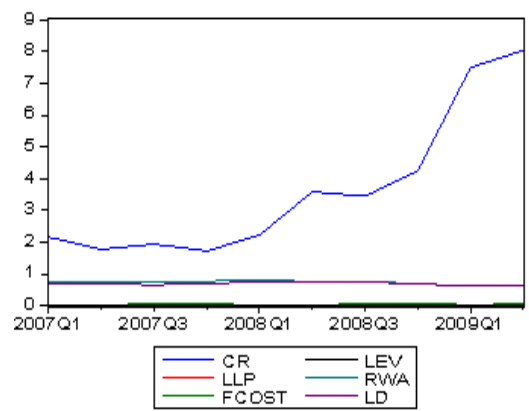

Islamic Banks 'Cr,Me,LnTA,Rcap'

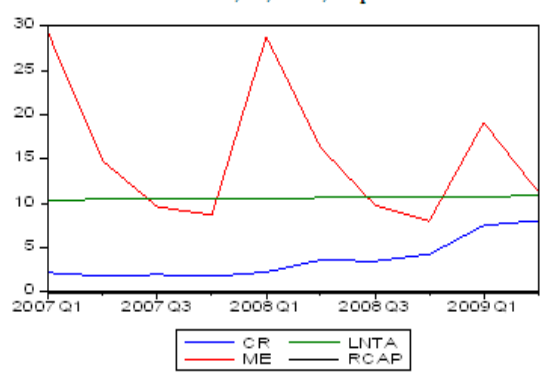

\subsection{The Model}

The equation for the model used in this study is:

$\mathrm{Cr}_{\text {it }}=\alpha_{0}+\alpha_{1} \operatorname{lnMe}_{\text {it }}+\alpha_{2} \operatorname{lnLev}_{\text {it }}+\alpha_{3} \operatorname{lnRcap}_{\text {it }}+\alpha_{4}$ $\operatorname{lnLlp} \mathrm{it}_{\mathrm{it}}+\alpha_{5} \operatorname{lnF}_{\text {cost }}+\alpha_{\mathrm{it}} \operatorname{lnRwa} \mathrm{Rit}_{\mathrm{it}}+\alpha_{7} \operatorname{lnTA_{\text {it}}}+\alpha_{8} \operatorname{lnLd}_{\mathrm{it}}+\epsilon_{\mathrm{it}}$

Where dependent variable is $C r_{i}$,

$C r_{i t}=$ Credit Risk $=$ non-performing loan to total loan of bank $\mathrm{i}$ in months $\mathrm{t}$

Following are independent variables

$M e_{i t}=$ Management efficiency $=$ earning assets to total assets of bank $\mathrm{i}$ in months $\mathrm{t}$

$\operatorname{Lev}_{i t}=$ Leverage $=$ tier 2 capital to tier 1 capital of bank $\mathrm{i}$ in months $\mathrm{t}$

$\operatorname{Rcap}_{i t}=$ Regulatory capital $=$ tier 1 capital to total assets of bank $\mathrm{i}$ in months $\mathrm{t}$

$L l p_{i t}=$ Loan loss provision $=$ loan loss provision to total loans of bank $\mathrm{i}$ in months $\mathrm{t}$

$F \operatorname{cost}_{i t}=$ Funding cost $=$ non-interest expenses to total (borrowings \& Deposits)

$R w a_{i t}=$ Risk weighted assets under Basel II of bank i in months $\mathrm{t}$

$\ln T A_{i t}=$ natural logarithm of total assets of bank $\mathrm{i}$ in months $\mathrm{t}$

$L d_{i t}=$ Proportion of Loan to deposit = total loans to total deposits of bank $\mathrm{i}$ in months $\mathrm{t}$

All the variables are transformed into logarithm to correct for non-linearity and to reduce multicollinearity.

\section{Empirical Results}

Following section analyses: the descriptive statistics, independent t-test of means of Islamic banks' and

\section{Conventional Banks Comparison}
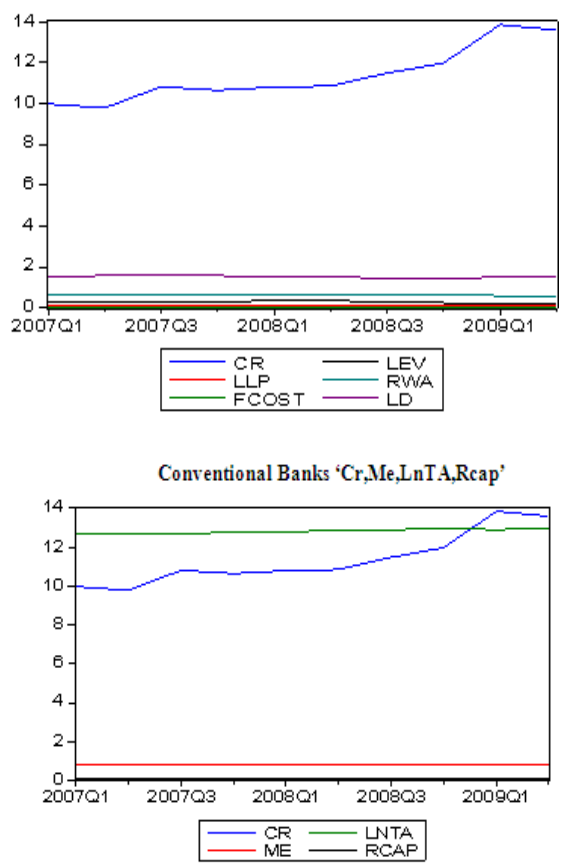

conventional banks' independent variables and presents regression results. Table 1 and Figure 1 show that the credit risk of Islamic banks did not follow the trend of the banking industry and that of the conventional banks. Their credit risks, though increasing gradually, are lower than the industry since start of 2007. This trend, which shows low credit risk borne by Islamic banks, is not similar to the findings of Samad and Hassan (1999).

Figure 1 below describes the impact of global financial crisis on the credit risk of Islamic banks, conventional banks and overall banking industry in Pakistan during 2007-2009.

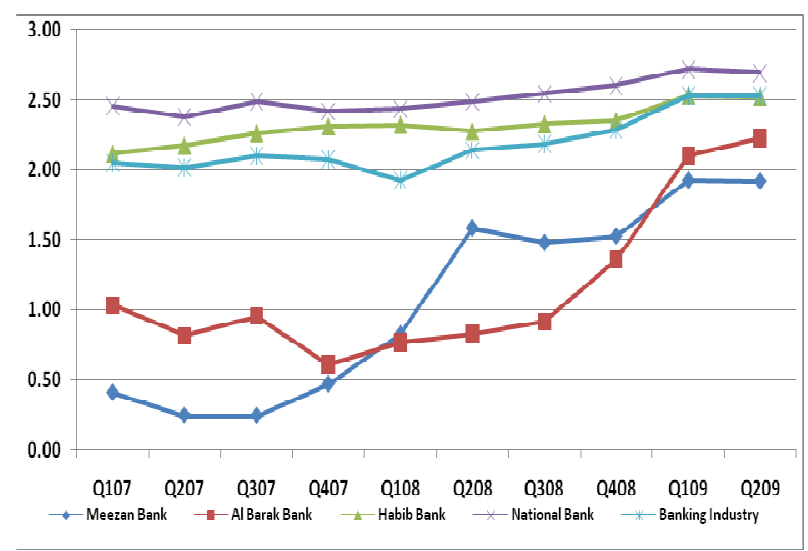

Figure 1. Credit risk (CR) of banking Institutions

To observe the distinction flanked by credit risk predictors of Islamic banks and conventional banks, independent t-test was performed. 
Table 1. Credit risk (Cr) of banks in Pakistan

\begin{tabular}{lllllllllll}
\hline & \multicolumn{3}{c}{$\mathbf{2 0 0 7}$} & \multicolumn{4}{c}{$\mathbf{2 0 0 8}$} & \multicolumn{3}{c}{$\mathbf{2 0 0 9}$} \\
Name of banks & $\mathbf{Q 1 0 7}$ & $\mathbf{Q 2 0 7}$ & $\mathbf{Q 3 0 7}$ & $\mathbf{Q 4 0 7}$ & $\mathbf{Q 1 0 8}$ & $\mathbf{Q 2 0 8}$ & $\mathbf{Q 3 0 8}$ & $\mathbf{Q 4 0 8}$ & $\mathbf{Q 1 0 9}$ & $\mathbf{Q 2 0 9}$ \\
\hline Meezan bank (\%)* & 0.41 & 0.25 & 0.24 & 0.47 & 0.83 & 1.58 & 1.48 & 1.53 & 1.92 & 1.92 \\
Al Barak bank (\%)* & 1.03 & 0.82 & 0.96 & 0.61 & 0.77 & 0.83 & 0.92 & 1.36 & 2.10 & 2.23 \\
Habib bank (\%)** & 2.12 & 2.17 & 2.26 & 2.31 & 2.32 & 2.27 & 2.33 & 2.35 & 2.53 & 2.52 \\
National bank (\%)** & 2.46 & 2.38 & 2.49 & 2.42 & 2.43 & 2.48 & 2.54 & 2.60 & 2.72 & 2.69 \\
Banking Industry (\%) & 2.05 & 2.02 & 2.10 & 2.07 & 1.92 & 2.14 & 2.18 & 2.28 & 2.53 & 2.53 \\
\hline
\end{tabular}

*Islamic banks $\quad$ **Conventional banks

Table 2 presents the statistical means of each variable and the test of equality. The analyses show that means of two (2) Islamic banking risk predictors are significantly different from their conventional counterparts. The two predictors that are not significantly different from those of conventional banking are Regulatory Capital (Rcap) and risk weighted assets (Rwa). The latter statistic suggests that the composition of Islamic banking risk weighted assets mirrors the risk weighted assets exposure of the conventional banks. The funding cost (Fcost) of Islamic banks is slightly higher than the conventional banks because of the less borrowing of Islamic banks than their conventional counter parts. This is a plus factor to Islamic banking, helpful in managing their credit. The mean of loan to deposit ratio (Ld) is also significantly different from conventional banking, shows efficiency of Islamic banks in disbursing less loans than deposits and gaining customers confidence in obtaining more deposits.

Table 2. Results of Independent T-test

\begin{tabular}{lllll}
\hline Variable & $\begin{array}{l}\text { Islamic } \\
\text { mean }\end{array}$ & $\begin{array}{l}\text { Conventional } \\
\text { mean }\end{array}$ & t-test & p-value \\
\hline Me & 15.617 & 0.823 & 0.279 & 0.827 \\
Lev & 0.017 & 0.277 & -0.602 & 0.655 \\
Rcap & 0.097 & 0.080 & -0.832 & 0.558 \\
Llp & 0.018 & 0.091 & 0.835 & 0.557 \\
Fcost & 0.039 & 0.027 & -0.097 & 0.939 \\
Rwa & 0.725 & 0.617 & 0.530 & 0.690 \\
LnTA & 10.565 & 12.825 & -0.471 & 0.720 \\
Ld & 0.690 & 1.510 & -0.916 & 0.528 \\
\hline
\end{tabular}

Table 2 illustrates that Islamic banking, on average had mobilized 69 percent of its deposits to give out financing to customers. This is a lower ratio compared to conventional banks, which had extended loans whose amounts were 1.510 times more than its deposits. This suggests a high probability of liquidity risk in the event of high default rate for conventional banks.

Tables $3.1 \& 3.2$ show the regression results of the factors influencing credit risk of Islamic banking (represented by Meezan bank \& Al Baraka Islamic bank) and conventional banking (represented by Habib bank \& National bank). For Islamic banks: Meezan bank has three variables i.e. Me, Lev, and Rwa which are significantly related to its credit risk. For Al Baraka Islamic bank, four variables i.e. Me, Lev, Fcost and $\mathrm{Ld}$ are significantly related to its credit risk.

For conventional banking: Habib bank has significantly influenced by 4 variables i.e. Rcap, Llp, Fcost and Rwa on credit risk. Similarly, National bank has 5 variables i.e. Rcap, Llp, Fcost, Rwa and Ld have significant influence its credit risk. The higher R-square of 96 percent in conventional banking compared to 54 percent in Islamic banking suggests that these variables collectively have a stronger influence on the credit risk of conventional banks than on the credit risk of Islamic banks.

The coefficient for Lev is positive but not a significant predictor of credit risk in both the Meezan bank and Habib bank. This finding is consistent with Berger and DeYoung (1997) and finance theory where higher debt has a high probability of higher credit risk from default payments.

The coefficients for Fcost are very small and not significantly related to credit risk in Islamic and conventional banks. The signs are not as expected but indicate that both banking systems might have incurred high overheads in monitoring and controlling functions to ensure credit risk and to minimize problem loans.

The regression results show that Rwa is significantly related to credit risk. The positive signs of the coefficients in both cases are consistent with Berger and DeYoung (1997) and Ahmad (2003). This result shows that a higher proportion of risky assets to total assets tend to have higher credit risk. Interestingly, the effect appears more pronounced in Meezan bank judging from its t-value 1.737 $(p=0.006)$ compared with t-value $-2.353 \quad(p=0.784)$ of Habib bank ltd., and t-value $-2.205(\mathrm{p}=0.494)$ of National bank of Pakistan. This finding confirms the intuitive insight of Sundararajan and Errico (2002).

Management efficiency, 'Me', coefficient of Islamic banks are positive and significant at 5 percent level. On the other hand, 'Me' is negatively related to credit risk of Habib bank. This result supports past findings (Ahmad, 2003; Angbazo et al, 1998). The positive sign of the coefficient in Islamic banking suggests that a higher proportion of earning assets to total assets, if not properly managed, would result in higher credit risk where an increase by 0.182 point in management efficiency would lead to a slight increase in credit risk. For the conventional 
bank, the negative sign denotes that a lower efficiency in managing its earning assets would lead to a higher credit risk. A possible answer for the opposite signs probably lies in the nature of the earning assets where they are all interest based in conventional banking and loan default is immediately recognized after 3 months of arrears in interests. In Islamic banking, the earning assets are largely on Murabahah and Mudarabah mode of financing, where the credit risk is transferred to its investment depositors and the loan defaults are not recognized (in case of Mudarabah on the part of the agent-entrepreneur until PLS contract expire (see Sundararajan and Errico,2002).

Table 3.1. Results of determinants of credit risk-Islamic banks (at 5\% level)

\begin{tabular}{lllllll}
\hline Variables & Coefficient & $\begin{array}{c}\text { Meezan bank } \\
\text { t- statistics }\end{array}$ & Probability & Coefficient & $\begin{array}{c}\text { Al Baraka bank } \\
\text { t- statistics }\end{array}$ & Probability \\
\hline Me & 0.182 & 1.033 & 0.490 & 0.03103 & 7.87 & 0.080 \\
Lev & 0.007 & 0.75 & 0.591 & -0.04 & 8.50 & 0.075 \\
Rcap & 0.016 & 0.2944 & 0.818 & -0.03006 & 1.74 & 0.331 \\
Llp & -0.047 & 0.689 & 0.169 & 0.04141 & 0.851 & 0.223 \\
Fcost & 0.002 & 0.2443 & 0.848 & 0.03435 & 6.96 & 0.091 \\
Rwa & 0.024 & 1.7373 & 0.006 & 0.01375 & 1.192 & 0.002 \\
LnTA & -0.021 & -0.5011 & 0.704 & 0.03384 & 2.29 & 0.261 \\
Ld & 0.028 & 0.6179 & 0.648 & -0.07067 & 6.74 & 0.094 \\
R-squared & 0.535 & & & 0.538 & & \\
DW & 3.34 & & & 3.17 & & \\
\hline
\end{tabular}

Table 3.2. Results of determinants of credit risk-Conventional banks (at $5 \%$ level)

\begin{tabular}{lllllll}
\hline Variables & Coefficient & $\begin{array}{c}\text { Habib bank } \\
\text { t- statistics }\end{array}$ & Probability & Coefficient & $\begin{array}{c}\text { National bank } \\
\text { t- statistics }\end{array}$ & Probability \\
\hline Me & -0.202 & -0.3797 & 0.769 & 0.7268 & 0.6141 & 0.649 \\
Lev & 0.007 & 0.0300 & 0.983 & -0.02 & -0.56 & 0.676 \\
Rcap & -0.059 & 1.9308 & 0.878 & 0.0288 & 2.3418 & 0.790 \\
Llp & -0.015 & -2.0215 & 0.986 & 0.1029 & 2.3679 & 0.254 \\
Fcost & 0.011 & 2.197 & 0.876 & 0.0041 & 2.5829 & 0.664 \\
Rwa & 0.237 & -2.3533 & 0.784 & 0.1409 & -2.0205 & 0.494 \\
LnTA & -0.076 & -0.1867 & 0.883 & 0.1016 & 0.6099 & 0.651 \\
Ld & -0.183 & -0.559 & 0.675 & 0.2667 & 3.2158 & 0.438 \\
R-squared & 0.963 & & & 0.964 & & \\
DW & 2.41 & & & 3.10 & & \\
\hline
\end{tabular}

Table 3.1 \& 3.2 show regulatory capital (Rcap) is negative and significantly related to credit risk of Habib bank. This is consistent with moral hazard theory postulate in Berger and DeYoung (1997) where smaller capitalized banks assume higher risk. The result in Meezan bank shows a contrast where Rcap coefficient is positive and not significant in its association with credit risk. A possible explanation is that Islamic banks do not in dire need to have a big capital base to cushion against losses since risks are absorbed by investment depositors /equity holders and losses are shared between entrepreneur and bank.

The coefficient estimate of Llp is positive and a significant predictor of credit risk in National banks. Consistent to past findings (Ahmed, 1998; Ahmad, 2003), the result suggest that a larger loan loss provision is required to cover higher non-performing loans and this indicates deterioration in loan quality as credit risk increases. In contrast, Llp coefficient in Meezan bank is negative but not significantly related to credit risk.

\subsection{Reasons for a Better Risk Management of Islamic Banks than Conventional Banks}

Less developed linkages with international markets have meant that the direct impact of the financial crisis has not been felt by the Pakistani financial sector. However; effects of the crisis have been felt, even though in a limited manner, by the real sectors of the economy. The effects of the global slowdown in Pakistan have been transmitted through the trade balance; with a slowdown in global demand and fall in commodity prices having varying effects, the capital account; with a significant reduction in private inflows to Pakistan.

Pakistan, which remained largely unscathed from a direct impact of the crisis, has been more concerned with issues 
relating to monetary stability due to rising inflation since before the advent of the crisis. With a thriving banking sector, increasingly resilient to a wide variety of shocks, increasing but still relatively less correlation of domestic financial markets with global financial developments, a proactive and vigilant regulatory environment, and most importantly, no direct exposure to securitized instruments, risks to financial stability were largely contained and well managed as the crisis unfolded and impacted the financial sectors in advanced economies.

Though overall Pakistan banking sector is less affected by global financial crisis, Islamic banks are succeeded in managing their credit risk due to their business nature, prohibition on the concept of banking on 'money on money' rather prefer to do business for social welfare through financing on asset backed banking. Islamic banks do not allow 'Financial derivatives' despite the fact that, they are frequently used by their conventional counterparts. This is one of the major reasons of safe side of Islamic banks from the awful effects of GFC on Islamic banks. Truly speaking, Islamic banks are infants to compete their conventional counter parts, 'the Giants', in the international capital markets. In our study, Habib bank and National bank have 60 overseas branches and are engaged in the international business of country's import/export, transfer of worker remittances and accumulation of Foreign Exchange reserves.

\section{Contribution to the Literature}

Based on literature reviewed so far, and specific methodology adopted for the present study, we can say that no one yet has investigated the impact of Global Financial Crisis on the credit risk Management of banks operating in Pakistan. Typically, studies on credit risk of banks have focused on theoretical issues and the empirical work has relied mainly on the analysis of descriptive statistics rather than rigorous statistical estimation. This study is an attempt to fill out the gap found in the literature on empirical analysis of Islamic banks operating in Pakistan with special focus on the impact of Global Financial crisis on the credit risk management of banks.

\section{Conclusion}

The primary impact for us to consider would be tightened terms for access to international debt markets; these are there for emerging markets in particular. Some countries will also need to assess how much their local banks may have invested in some of the problematic instruments that have surfaced. In our case, though this is probably minimal and our banks have benefited from pretty effective financial sector reforms too, thus improving resilience to international shocks.

According to banking theory, banks exist because they create liquidity and transform risk. Efficient risk management capacity is necessary to enable banks to strategically position themselves in the global market by reducing their overall risk exposure. The absence of robust risk management systems may deprive banks from the ability to hedge risks, and could undermine their potential contribution. Adequate resources need to be devoted to risk identification and measurement as well as the development of risk management techniques

This paper has examined the impact of global financial crisis on the credit risk management of banks operating in Pakistan during the period, 2007-2009 and found that, even as the Islamic banking industry has not been left unreceptive of the global crisis, they found in a relatively strong position. This is because of the industry's high levels of transparency and adherence to a strict code of business conduct and Management efficiency, which means that Islamic banks have the potential to emerge from the crisis in a stronger position than their conventional counterparts.

The findings show that the GFC could not severely affected credit risk of Islamic banks (the management efficiency, risk-weighted assets and size of total assets), while conventional banking credit risk is significantly affected by GFC showing their impact on the variables of credit risk viz: regulatory capital, loan loss provision and risk-weighted assets. While both observe similar effects of leverage, funding cost, risk-weighted on credit risk, Islamic banking experiences different impact of management efficiency, regulatory capital and loan loss provisions on their credit risk. Since hedging is not possible in Islamic banking operations, reducing adverse selections and strengthening internal controls are suggested as measures to increase efficiency in mitigating credit risk in Islamic banks.

The Global Financial Crisis and the accompanying global credit crunch had a minor direct impact on Pakistan.

\section{Recommendations}

Future growth will only come with innovation which has assumed certain negativity in the light of the global financial crisis. To meet the future challenges of global financial services, the financial sector needs to be further regulated. The reputation of the bank would be adversely affected by negligence or misconduct. Even a financially sound bank could be exposed to the risk of failure as a result of losing the confidence of its depositors, who would withdraw their funds. Fiduciary risk also exposes both equity holders and investment depositors to risk of economic losses as they would not receive their potential profit share as a result of the bank's misconduct. Lack of transparency creates a risk of incurring losses due to bad decisions based on incomplete or inaccurate Information. A larger proportion of risk-weighted assets tend to have higher probability of credit risk. Financial institutions are recommended to exercise transparency in disclosing information for better decision making and adopt early warning systems to avoid shocks of plausible financial crisis.

Further research is proposed to investigate the managerial efficiency of Islamic banking Sector in SAARC countries with special focus on credit risk. 
Jel Classifications: C40, D81, G21, G33

\section{References}

[1] Abdus Samad \& M. Kabir Hassan (1999), the performance of Malaysian Islamic banks during 1984-1997: An explanatory study, International journal of Islamic Finance, vol. 1 No.3

[2] Ahmad \& Nor Hayati, (2003), "Formation of credit risk, Price Effect of Regulatory Changes and the Path Linking credit risk and total risk", $\mathrm{PhD}$ Thesis, University Utara Malaysia.

[3] Ahmed, A.S., (1998), "bank Loan Loss provision: A reexamination of capital management, Earnings Management and Signaling Effects", Syracuse University, Syracuse: $1-37$.

[4] Angbazo, L.A, Mei, J. and Saunders, A(1998), "Credit spreads in the market for highly leveraged transaction loans", Journal of banking and Finance 22: 1249-1282.

[5] Arby, M. Farooq (2003), Structure and performance of commercial banks in Pakistan, MPRA paper no. 4983, posted 07 . November 2007 pp 4-21

[6] Bartlett, D., 2008, "Fallout of the Global Financial Crisis" Davis E.P., Karim, I., 2007, "comparing early warning systems for banking crises" Journal of Financial Stability 4 (2008) pp 89-120

[7] Berger, Allen N and DeYoung, Robert (1997), Problem Loans and Cost Efficiency in Commercial banks, Journal of banking and Finance 21: 849-870.

[8] Cafer and Ferhan, (2005), Intermediation Cost and Financial Fragility, Research Department, Istiklal Cad, Central bank of Turkey, Ankara, pp 1-16

[9] Corsetti, G, P. Pesenti, and N. Roubini, (1998), Fundamental Determinants of the Asian Crisis: a preliminary empirical assessment, paper prepared for the JIMF-Fordham University Conference on "Perspectives on the Financial Crisis in Asia".

[10] DeBeers, R.D., 2008, Understanding the Financial Crisis: Origin and Impact.

[11] Erkkilä, M., 2008, Impact of financial crisis on the Russian economy

[12] Dr Rakesh Mohan, Global Financial Crisis - causes, impact, policy responses and lessons, Deputy governor, Reserve bank of India, Business forum Conference, London Business School

[13] Gurria, A., 2008, "The Global Financial Crisis: Where to next, and what does it mean for OECD countries?"

[14] Hamid Ibrahim and Naseer Ibrahim (2007), Islamic banking and Finance, Gavel Publications ltd., Malaysia

[15] Hassan, M. K. and Bashir, A. H(2002), Determinants of Islamic banking Profitability, ERP paper.

[16] Hillson and Ruth Murray (2007), Understanding and managing risk attitude, 2nd ed. Gower publishing 1td. England
[17] Hyun-Soo, P., 2008, "Future Direction of the Global Financial Crisis" Khatiwada S., McGir E., 2008, "Financial Crisis: a review of some of the consequences, policy actions and recent trends."

[18] John B. Caoutte et al (2008), the great challenge for Global financial market, $2^{\text {nd }}$ ed. Gower publishing ltd. England

[19] Khan, T. and Ahmed H (2001), risk Management -An Analysis of Issues in Islamic Financial Industry, Islamic Development bank-Islamic Research and Training Institute, Occasional Paper no.5 Jeddah.

[20] Iqbal, Z. and A. Mirokhar, (1987), Islamic banking, Occasional paper \# 49, IMF

[21] Lampros Kalvys and Loannis Akkizidis (2006), Integrating market credit and operational risk,

[22] Michal et al 2006, Financial Publications ltd.

[23] Mohammed Mansoor Ali, 2009, Global Financial Crisis: Impact on Pakistan and Policy Response, Regional HighLevel Workshop on "Strengthening the Response to the Global Financial Crisis in Asia-Pacific: UNITED NATIONS ECONOMIC AND SOCIAL COMMISSION FOR ASIA AND THE PACIFIC Dhaka, Bangladesh, 27-30 July 2009

[24] M. Y. Khan (2001), banking regulations and Islamic banks in India: Status and Issues, International Journal of Islamic Financial Services Vol. 2 No.4

[25] Nicholson, R., et al, 2008, "Impact of the Financial Crisis on Technology Spending in the Utility Industry"

[26] Peter F. Christoffersen (2003), Elements of financial risk management, Academic Press, Oxford New York

[27] Rasmus, J., 2008, 'The Deepening Global Financial Crisis: From Minsky to Marx and Beyond', Journal of Socialist Theory, 36:1, pp 5-29

[28] Rose, Peter S., (1996), "Commercial bank Management", McGraw Hill Cos. Inc. USA: 196-190

[29] Seref Turen (1996), Performance and risk Analysis of the Islamic banks: The Case of Bahrain Islamic bank, J.KAU: Islamic Econ., Vol. 8, pp. 3-14

[30] Shrieves, Ronald, E and Dahl, D (1992), "The Relationship between risk and Capital in Commercial banks", Journal of banking and Finance 16: pp 439-457

[31] State bank of Pakistan, (2009), Pakistan's Islamic banking Sector Review, Islamic banking Department, SBP, Karachi.

[32] Stephen G. Cecchetti, (2008) Crisis and Responses: The Federal Reserve and the Financial Crisis of 2007-2008, bank of International settlement (BIS), Monetary \& Economic Department, CEPR, National Bureau of Economic Research-NBER Working Paper No. W14313

[33] Sufian, et al (2007) bank Ownership, Characteristics and Performance: A Comparative Analysis of Domestic and Foreign Islamic banks in Malaysia, MPRA Paper No. 12131, posted 12. December 2008, pp 19-30

[34] Sundararajan, V and Errico, L (2002), Islamic Financial Institutions and Products in the Global Financial Systems: Key Issues in risk Management and Challenges Ahead: IMF Paper WP/02/192 
[35] Warne, K., "Gaining a better understanding of the financial crisis", Canadian Strategy Report.

[36] William H. Buiter, (2007) Lessons from the 2007 Financial Crisis, London School of economics \& Political Science, NBER, SSRN-Lessons
[37] World Economic Forum, 2008, "Network of Global Agenda Councils", Summit on the Global Agenda, Dubai, United Arab Emirates 7-9 November 2008

[38] Y1lmaz, K., 2008, "Global Financial Crisis and the Volatility Spillovers across Stock Markets" 